\title{
Pierre Adolphe Piorry (1794-1879): pioneer of percussion and pleximetry
}

\author{
ALEX SAKULA \\ From the Redhill General Hospital, Redhill, Surrey, UK
}

\begin{abstract}
Piorry was born in Poitiers on 31 December 1794. As a medical student he served in the Napoleonic war in Spain. His teachers in medicine included Corvisart, Bayle, Broussais, and Magendie; he qualified in 1816 with an MD thesis: "On the danger of reading medical text books by the laity"! Laënnec's invention of the stethoscope (1816) and De l'Auscultation Médiate (1819) inspired Piorry to make an analogous contribution to the technique of percussion (which had been originally described by Auenbrugger in his Inventum Novum in 1761 and translated from the Latin into French by Corvisart in 1808). This led to Piorry's invention in 1826 of the pleximeter (le plessimétre) to help outline the internal organs (l'organographisme), which he described in De la Percussion Médiate (1828).

Piorry became renowned as a professor of medicine in many of the great Parisian hospitals (Charité, Pitié, and Hôtel Dieux). In 1832 he was appointed to L'Hospice de la Salpétrière, where he held a famous course of clinical lectures. He wrote prolificly on many aspects of medicine and published more than twenty books. He was, in addition, a poet of some distinction, and wrote a remarkable long poem Dieu, L'Ame et la Nature (1853). Piorry held very idiosyncratic views on the nomenclature of disease (l'onoma-pathologie), although some of his neologisms - for example, toxin, toxaemia, septicaemia, etc.-are still in use. This, together with the mixed reception that his advocacy of pleximetry received from his medical contemporaries, made him a controversial figure. He died on 29 May 1879.
\end{abstract}

The first three decades of the nineteenth century saw rapid advances in the technique of clinical examination, which were largely initiated by the Paris School of Medicine. The great French masters, such as Jean Corvisart (1755-1821), Gaspard Bayle (1774-1816), René Laënnec (17811826), and François Broussais (1772-1838), led the way in clinical diagnosis. Among this galaxy one of the great stars was Pierre Adolphe Piorry (fig 1), whose controversial method of médiate percussion helped to sharpen the diagnostic skills of clinicians both in France and elsewhere.

\section{Piorry's early years}

Pierre Adolphe Piorry was born in Poitiers on 31 December 1794. He showed great promise in his early schooling, and in 1810 began his medical studies. In 1813, aged 19, he was conscripted as a medical student to be aide-chirurgien militaire during the Napoleonic campaign in Spain, and he spent fifteen months at the Atarazanas Hospital in
Barcelona, where he was able to witness military surgery and studied hospital gangrene, febrile jaundice, and syphilis. In 1814 he returned to his medical studies in Paris, and was fortunate to be taught by some of the greatest French clinicians of the time-among them Corvisart and Bayle. He qualified in 1816, aged 22 , with an MD thesis on the danger to laymen of reading medical books ("Sur le danger de la lecture des livres de médecine par les gens du monde")!

After qualification, he worked with, and was considerably influenced by, François Magendie (1783-1855) and Broussais, at Le Charité and $\mathrm{La}$ Salpétrière hospitals, and from 1823 to 1825 he was resident at L'Academie de Médecine. His special gift as a teacher was soon appreciated, and he delivered a regular course of lectures in physiology and pathology, which continued annually from 1817 to 1826 . In 1826 he succeeded, by public competition, in being appointed physician to the Paris hospitals, and in 1827 he became Médecin du Bureau de Bienfaisance du 4e Arrondissement and 


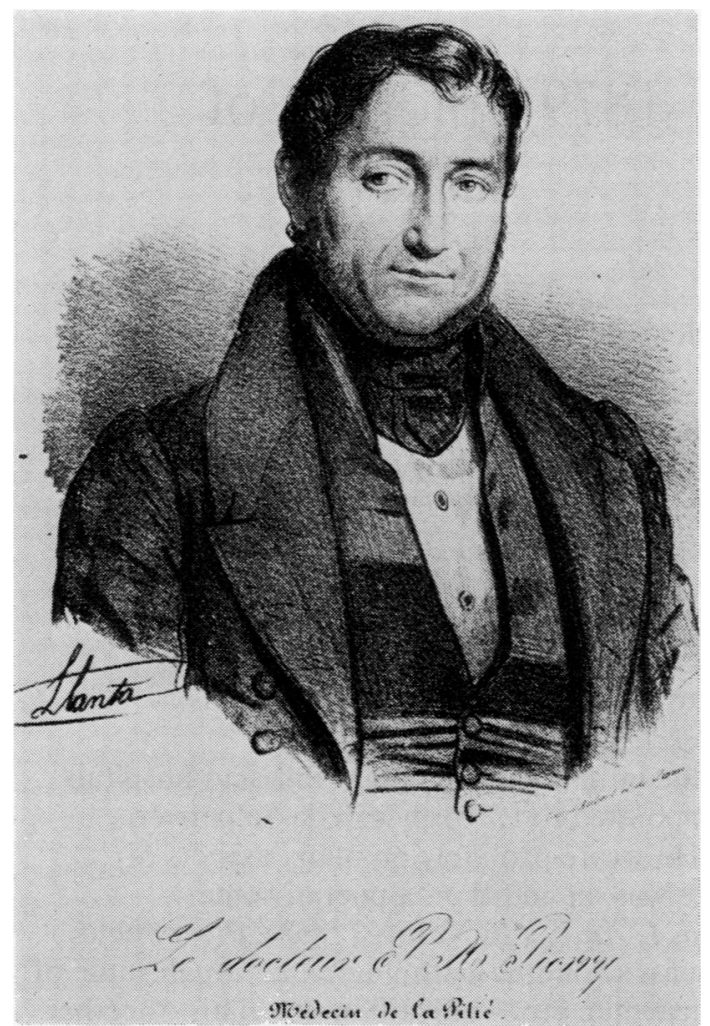

Fig 1 Pierre Adolphe Piorry. Lithograph by J Llanta in the Wellcome Institute.

of the Bureau Central, Paris. His ambition was to become a professor at the Paris School of Medicine, and he applied for several vacant chairs but without success. In 1832 he was appointed to L'Hospice de la Salpétrière, and for the next five years he conducted a very popular course of lectures in clinical medicine, as well as teaching morbid anatomy at L'Ecole Pratique. He was at last successful, and in 1837, aged 43, obtained the chair of medicine at L'Hôpital de la Pitié, Paris.

\section{Percussion before Piorry}

Percussion as a clinical technique had been introduced by the great Austrian physician, Leopold von Auenbrugger (1722-1809), who described the method in 1761 in his Inventum Novum. This little book of 95 pages, written in Latin, attracted some interest at the time, but the method was virtually ignored by Gerard Van Swieten (170072), then professor of medicine in Vienna, and also by his successor, Anton de Haen (1704-76). Maxi- milian Stoll (1742-87), who followed de Haen, favoured the method, and described it in his Aphorisms, and Albrecht von Haller (1708-77) also considered it to be of some value. After twenty years, however, the technique of percussion was virtually abandoned in Vienna. In 1770 Rozière de la Chassagne in Montpellier referred to Auenbrugger's method of percussion but misconstrued it as a variant of Hippocratic succussion (Sakula, 1978). Percussion was then almost completely forgotten until Corvisart (later physician to Napoleon, and then created a baron), having read of percussion in Stoll's Aphorisms, decided to translate Inventum Novum from the original Latin into French, and he had the work published in Paris in 1808, only one year before Auenbrugger's death (Corvisart, 1808).

Auenbrugger described the technique of percussion as follows:

"Observation 2: Of the Method of Percussion.

IV The thorax ought to be struck, slowly and gently, with the points of the fingers brought close together and at the same time extended.

V During percussion the shirt is to be drawn tight over the chest, or the hand of the operator covered with a glove made of unpolished leather.

Scholium: If the naked chest is struck by the naked hand, the contact of the polished surfaces produces a kind of noise which alters or obscures the natural character of the sound."

Corvisart's technique differed from that of Auenbrugger in that he used the palmar surface of the extended and approximated fingers ("à main ouverte").

Mediate percussion and invention of the pleximeter

The year 1816, when Piorry qualified, was a momentous one in the history of clinical medicine as it was the year that Laënnec invented the stethoscope. During the next few years Laënnec perfected its use as a method of médiate auscultation and was enabled to make his great contribution to the clinicopathological correlation of pulmonary and cardiac diseases, which he described in De l'Auscultation Médiate, published in 1819. Laënnec himself had been stimulated by Corvisart's translation of Auenbrugger's work, and he practised manual percussion. After he had devised the stethoscope he often used this instrument also for percussing the chest. The introduction of the stethoscope, however, tended to 
emphasise the importance of auscultation, and percussion became even less popular.

Piorry, enthused by Laënnec's invention, developed an ambition to emulate the great master and to achieve fame in some similar fashion. Piorry describes in his poem Dieu, L'Ame et Nature how he came to study percussion. He prayed to God asking to be able to make some discovery like that of Laënnec. A few months later he had slight pruritus and while scratching the skin over his chest he heard a sound. He interposed a coin and scraped it and obtained a stronger sound, which varied according to the density and elasticity of the underlying organ. The next day, at l'Hôpital de la Pitié, he began his work on médiate percussion. What Laënnec had done for auscultation Piorry hoped to achieve for percussion. On 28 February 1826 he read a prizewinning paper on his new method of percussion to

\section{DE}

\section{LA PERCUSSION MÉdIATE \\ ET DES SIGNES}

OBTENos a L'ame DE CE NOUVEAU MOTEN D'BXPLORATION,

DANB LES MALADIES

DES ORGANES THORAGIQUES ET ABDOMINAUX.

PAR P.-A. RTomaX,

Doctear en Médecine, Agrégé près la Faculté de Mbédecine de Paris, Prefesseur de physiologie et de pathologie, Médecin du Bureau central d'Admission dans le hópitanx, Membre de PAcadímie royale de MÉdecine, de la Societé de Mídecine, du Cercle médiceal de la Sociáté́ médiceto de Tours, de r'A

Médecine de Madria, Médecin du Barasu de Charité du $q^{\circ}$ Arrondissement, ec.

Un organe thant diane, cherrber a dátarminaer

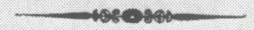

\section{paris,}

J.S. CHAUdÉ, LIBRAIRE, RUE DE LA HARPE, No 56 ; ET J.-B. BAILLIERB, LIBRAIRE,

nUs $x x$ vis-A-YIs L' A LONDRES, MEME MAISON,

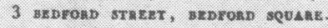

$$
1828 \text {. }
$$

Fig 2 Title page of De la Percussion Médiate (1828). the Académie Royale de Médecine. Laënnec (then very near his death) was one of those present.

Piorry's innovation was to interpose a small plate between the skin and the percussing finger. He believed this method to be an advance on direct percussion, as in addition to improving the sound, direct percussion could be painful and fatiguing to the patient, and skin diseases also complicated the procedure (Risse, 1971). He called the small plate a plessimétre (pleximeter, in English), derived from the Greek: $\pi \lambda \eta \sigma \sigma \omega$ to strike, $\mu \epsilon \tau \rho o \nu$ to measure. In 1828 he published his famous work Le plessimétre ou de la Percussion Médiate (fig 2), which he dedicated to the departed spirits (les mânes) of Auenbrugger, Corvisart, and Laënnec.

Just as Laënnec had experimented with various materials for his stethoscope, so Piorry tried plates made of lead, leather, cedar wood, and horn, but finally settled on a small ivory plate, $5 \mathrm{~cm}$ in diameter. He also devised a combined stethoscope and pleximeter made of ivory and cedar wood (fig 3). Some clinicians later used a small rubber tipped hammer as percussor (the plessor), but Piorry preferred to use his fingers to percuss the pleximeter. Many foreign physicians, including British and American, visited Piorry's clinics in Paris to learn the technique, and some preferred using the finger of one hand as pleximeter, and the finger of the other hand as percussor. This became the method favoured by Pierre Louis (1787-1872) and Armand Trousseau (1801-67) in Paris, by Josef Skoda (1805-81) in Vienna, and by William Stokes (1804-78) in Dublin. The finger-to-finger method is that in general use today, and has the advantage of providing an additional "feel" to percussion, for instance, the stony dullness over fluid.

\section{Organographism and organopathism}

Médiate percussion and the pleximeter were not adopted by all Piorry's contemporaries, and there were many who regarded the method as superfluous, revolutionary, and bizarre. Piorry did not regard percussion as competing with auscultation, and taught that the two techniques were supplementary one to the other. He persevered with his experiments on both the living and the dead subject, developing the technique for outlining the organs in the thorax and abdomen, which he designated l'organographisme (fig 4). A familiar and characteristic sight at his clinical demonstrations at the Pitié was Piorry sitting on a high stool, which was moved from bed to bed, and by careful plexmetry he mapped out the patient's organs 


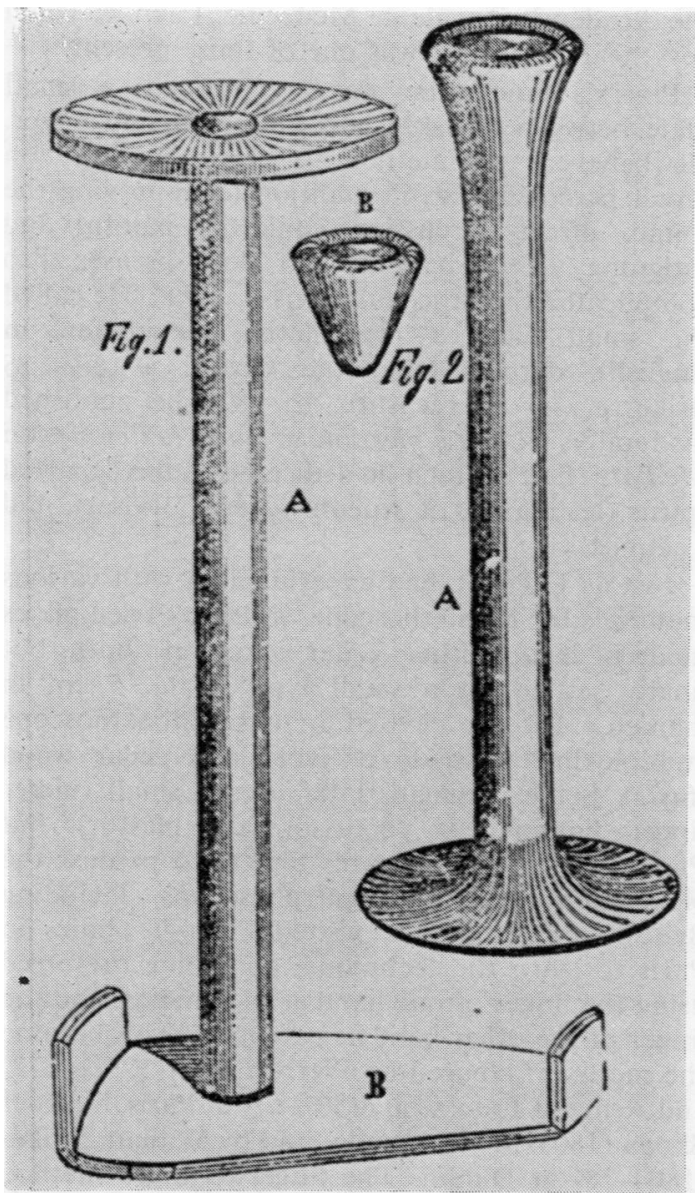

Fig 3 Pleximeter and stethoscope. Reproduced from Piorry's Exposé Analytique (1856).

on the skin, using coloured crayons, so that the patient's torso ended up looking like a geographical map (Gueniot, 1927). He tried to convince observers that every organ had a special percussion sound, and he played on his pleximeter like a virtuoso on a musical instrument. He came to be known as the "medical Paganini" (Ebstein, 1911). There were many anecdotes, no doubt fictitious, related about him, such as that he paid a visit to the Royal Palace in the Tuilleries and demanded to see the King, but was told that the monarch was not in his reception room. Piorry then decided to percuss the closed door with his pleximeter, detected a certain dull sound and diagnosed the presence of the King in his chamber (Monpart, 1902)!

Piorry emphasised the importance of studying both the anatomy and function of the bodily organs, in health and disease, and the necessity for diagnosis of organ disease to be precise, otherwise treatment was difficult. To this concept he gave the name l'organopathisme.

\section{Piorry's other medical writings}

Apart from his famous works on médiate percussion and pleximetry, Piorry was a prolific writer on other clinical subjects (see Appendix). Between 1818 and 1822 he made numerous contributions to the Dictionaire des Sciences Médicales and the Journal de la Societé de Médecine. One of these needs to be especially noted, his pioneer study in 1823 on meningitis in infants ( $D e$ l'irritation encephalique chez les enfants). He also later published his Traité de Medecine Pratique in 10 volumes (1841-51) which included, in 1843, his famous paper on changes in the blood (Traite des Alterations du Sang). Piorry was the first to consider a quantitative method of counting red blood cells.

"On pouring drops of blood of different cases in some grams of fluid such as a solution of sodium sulphate, which had no dissolving effect on red cells, and after mixing, one examines a given volume (a droplet on the end of a sharp end of a needle), one would be able to evaluate (but only approximately) the relative proportions presented by different kinds of blood" (Dreyfus, 1957).

In all Piorry published some 25 volumes on medical subjects, and his individual papers if collated would probably amount to another 30 or more volumes.

\section{Piorry's revision of medical nomenclature}

Piorry was a great linguistic innovator. $\mathrm{He}$ attempted to revolutionise the nomenclature of disease by creating what he considered to be a rational and consistent system of medical terms, derived from the Greek. He objected to eponymous names for medical conditions, especially when, as in "Skodaic resonance," the physician honoured was a foreigner! He created numerous new medical terms, some of them extremely pedantic, much to the chagrin of his medical contemporaries. One of them, Bousquet, is reported to have protested: "Laissez ce detestable neologisme."

Some of the terms he tried to introduce were certainly very cumbersome, for instance, neiloiémonévraxilé or dysloiémonévraxilé. He even renamed his plessimétre and suggested calling it a 


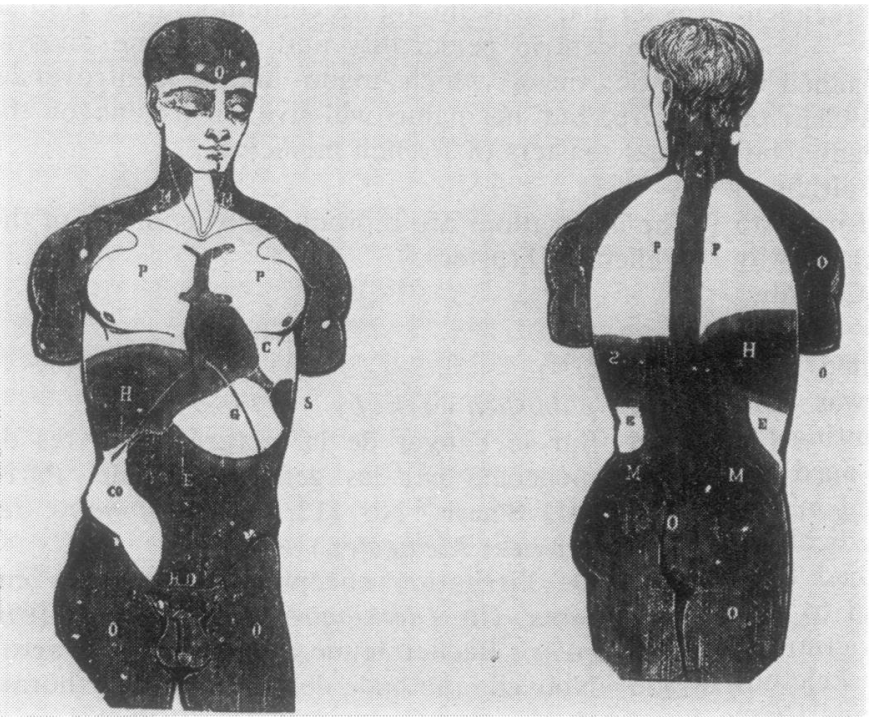

Fig 4 Example of organographism. Reproduced from Piorry's Exposé Analytique (1856).

"placeplesse." Some of the words, on the other hand, were reasonable, such as thyromegalie instead of goitre. Many terms he introduced were adopted universally and are still in use today -for example, toxin, toxaemia, septicaemia. A small dictionary of his medical terminology is included in his Atlas de Plessimétrism (1851). This purification of the medical nomenclature was a favourite hobby-horse of Piorry, and to it he gave the name l'onoma-pathologie.

\section{Piorry's poetry}

As a young medical student, aged 19, Piorry composed a poem based on the exploits of Napoleon, and he dedicated it to the Emperor. Piorry had a pronounced literary and philosophical bent, and in later years he continued to write poetry, his greatest poem being Dieu, L'Ame et la Nature (God, Soul and Nature) published in 1853. This was a very ambitious work, in eight cantos and 2526 verses. The style of the poetry tends to be rather turgid, the ideas expressed are somewhat highflown, and the phraseology rather pompous. He speaks of the origin of the universe, Man's progress on earth, the development of civilisation, and the possibilities for the future. God is his inspiration, even in his scientific work. In this poem he refers to Laennec's introduction of the stethoscope, and to his own discovery of médiate percussion, his invention of the pleximeter, and his l'organographisme. He also expresses a horror of war, no doubt based on his experiences in Barcelona in 1813 (Le Gendre, 1927).

\section{Piorry's personality}

Contemporary portraits of Piorry show him to have a tall imposing figure and head with a thick dark beard cut below the chin, a pale face, quizzical eyes, a long thin nose, and thin lips. He wore his cravat loosely over his chest, unlike his contemporaries whose cravat was worn stiffly around a high collar, and he was described as looking at times more like an old sea-salt rather than an intellectual ("Comme d'un vieux loup de mer que d'un savant") (Le Gendre, 1927). When teaching he presented a solemn face, rarely smiled, but behaved with great self-assurance and authority, speaking rather long-windedly with much gesticulation. His repartees could be very biting and sarcastic.

There was however a lighter side to his character. He was able to attract the opposite sex, loved music, played the violin well, was an excellent dancer, and an accomplished fencer. A born original and eccentric, he enjoyed being the centre of controversy. Many of his contemporaries held very uncomplimentary views of him, from being a colossal bore to being a violent revolutionary (Guardia, 1884).

\section{Piorry's later years}

From the chair in medicine at La Pitié Piorry moved to the chair in internal pathology in 1840 , to the chair in clinical medicine at Le Charité in 1850 , and he then succeeded Trousseau as professor of medicine at L'Hôtel Dieu in 1864 . He was 
now famous throughout Europe and the recipient of many honours.

In 1866 , when aged 72 , he was approached by the Minister who asked him to resign his chair on the grounds of age. Piorry took this badly, but nevertheless did hand in his resignation although he let it be known that he had been forced to give up against his will (Busquet, 1929/31). By way of compensation, he was in 1866 created Chevalier de la Légion d'Honneur.

After his retirement Piorry remained very energetic and active, and his advice was constantly sought by younger colleagues. During the Paris Commune in 1871, Piorry, then aged 76, was named "chirurgien de bataillon" and in this capacity he was asked to provide medicolegal verification of eighteen skeletons that had been discovered in St Lawrence's Church, and to give an opinion on whether they were the "victims of the clergy." Piorry reported that the skeletons were all female, and they had been buried there many years previously.

Piorry's last years passed uneventfully, and he died in his house in Paris, at 24 Avenue de Wagram, on 29 May 1879, aged 85. The Lancet of 7 June 1879 carried an obituary notice, the first paragraph of which read as follows:

"One of the most remarkable figures of contemporary medicine in France has just departed this life. He seemed invulnerable, so well did he bear the encroachments of age, and at his advanced time of life he would be seen in the forum of the Paris Academy of Medicine as erect, as firm, and as ardent as ever, fighting his hundredth fight for some favourite theme of medical nomenclature, or some cherished theory in pathology. He has, however, succumbed after a laborious career, full of good work and well deserved honours." (Lancet, 1879)

\section{Conclusion}

Pierre Adolphe Piorry was undoubtedly one of the most gifted and extraordinary medical men of his time. Following in the tradition of the great French clinicians of the beginning of the nineteenth century, he made important contributions of the highest scientific value in many branches of medicine. His major work was to pioneer the method of percussion, using the pleximeter that he invented. He no doubt exaggerated the importance of his invention, which is no longer in use today, but his teaching and prolific writings helped to encourage careful clinical examination and exact diagnosis among his contemporaries. He had an eccentric personality and held some idiosyncratic views, which made him a controversial figure, but his name will live on as one of the great masters of French medicine.

The illustrations are reproduced by courtesy of the Wellcome Trustees.

\section{Appendix}

Major published works by $P$ A Piorry

1816 Sur le danger de la lecture des livres de médecine par les gens du monde. Paris, MD Thesis, No 112. (In Dictionaire des Sciences Médicales.)

1823 De l'irritation encephalique chez les enfants. (In Dictionaire des Sciences Médicales.) Bechet Jeune and Delaunay, Paris.

1826 Nouvelle méthode de percussion du thorax. Archives of General Medicine, 10, 471.

1828 De la Percussion Médiate. J S Chaudé et J B Baillière, Paris.

$1831 \mathrm{Du}$ Procédé Opératoire à suivre dans l'Exploration des Organes par la Percussion Médiate. J B Baillière, Paris.

1835 Clinique Médicale de l'Hôpital de la Pitié et de l'Hospice de la Salpétrière en 1832. J B Baillière, Paris.

1837 Traité de Diagnostic et de Séméiologie. A D Wahlen et Cie, Brussels.

1841- Traité de Médecine Pratique (10 vols).

51 J B Baillière, Paris.

1841 Nomenclature organo-pathologique. (In Traité de Médecine Pratique.)

1843 Traité des Alterations du Sang. (In Traité de Médecine Pratique.)

1851 Atlas de Plessimétrisme. (In Traité de Médecine Pratique.)

1853 Dieu, L'Ame et la Nature. J B Baillière, Paris.

1855 De la Doctrine des Etats Organopathiques ou de la Nomenclature Organopathologique. J B Baillière, Paris.

1856 Exposé Analytique des Principaux Travaux D'Anatomie ... J B Baillière, Paris.

1864 La Médecine du Bon Sens. Adrian Delahaye, Paris.

1866 Traité de Plessimétrisme et d'Organographique. Adrien Delahaye, Paris.

\section{References}

Auenbrugger, L (1761). Inventum Novum. Trattner, Vienna. 
Busquet, P (1929-31). Pierre-Adolphe Piorry. Les Biographies Medicales, 2, 213-222; 227-236.

Corvisart, J N (1808). Nouvelle Methode (Translation of Auenbrugger's Inventum Novum). Mignaret, Paris.

Dreyfus, C (1957). Some Milestones in History of Haematology. Grune and Stratton, London and New York.

Ebstein, E (1911). Das Plessimeter ein beitrag zur geschichte der mittelbaren perkussion. Sudhoff's Archives, 4, 50-56.

Guardia, J M (1884). Histoire de Médecine. O Duin, Paris.

Gueniot, A (1927). Souvenirs, Anecdotes et Médicaux. J B Baillière, Paris.

Lancet (1879). Obituary, Professor Piorry. 1, 827.
Laennec, R T H (1819). De L'Auscultation Mediate. Brosson and Chaudé, Paris.

Le Gendre P (1972). Opinions et caractere de P A Piorry-A propos de son poème: "Dieu, L'Ame et la Nature." Bulletin de la Societé Française D'Histoire de la Médecine, 21, 436-459, 22, 57-82.

Monpart, A (1902). Piorry. Journal de la Santé, 1, 241-242.

Risse, G B (1971). Pierre A Piorry (1794-1879), the French "Master of Percussion." Chest, 60, 484 488.

Sakula, A (1978). Auenbrugger: Opus and Opera. Journal of the Royal College of Physicians, 12, 180188.

Requests for reprints to: Dr A Sakula, Redhill General Hospital, Redhill, Surrey.

\section{Symposium on Thoracoscopy}

Marseilles, France: 24-25 April 1980

Organised by: Department of Pneumology, Cancer Institute, Medical School, Marseilles.

\section{Programme}

24 April, afternoon: demonstration of thoracoscopy; magnetoscopic and motion picture session.

25 April, 9 am-5 pm: Methods, materials, anaesthesia, results in spontaneous pneumothorax, cancer, and non-cancerous effusions. Comparison with cytology, needle biopsy, transbronchial biopsy, surgical biopsy. Talc poudrage in pneumothorax and pleural cancer.

Simultaneous translation French-English.

Further details may be obtained from: Professor Ag C Boutin, Institut PaoliCalmettes, 232 bd Ste-Marguerite, 13009 Marseilles. Tel 7590 86/75 3068. 